Portland State University

PDXScholar

Women, Gender, and Sexuality Studies Faculty

Publications and Presentations

Women, Gender, and Sexuality Studies

2018

\title{
"Diversity," Anti-Racism, and Decolonizing Service Learning in the Capstone Experience
}

W. Tracy Dillon

Portland State University

Judy BlueHorse Skelton

Portland State University, judyblue@pdx.edu

Vicki Reitenauer

Portland State University, vicr@pdx.edu

Follow this and additional works at: https://pdxscholar.library.pdx.edu/wgss_fac

Part of the Curriculum and Instruction Commons, and the Curriculum and Social Inquiry Commons

Let us know how access to this document benefits you.

\section{Citation Details}

Dillon, W.T., Skelton, J.B., \& Reitenauer, V.L. (2018). "Diversity," Anti-Racism, and Decolonizing Service Learning in the Capstone Experience. The Journal of General Education 67(3), 194-208.

This Article is brought to you for free and open access. It has been accepted for inclusion in Women, Gender, and Sexuality Studies Faculty Publications and Presentations by an authorized administrator of PDXScholar. Please contact us if we can make this document more accessible: pdxscholar@pdx.edu. 


\section{"Diversity," Anti-Racism, and Decolonizing Service Learning in the Capstone Experience}

W. TRACY DILLON, JUDY BLUEHORSE SKELTON, AND VICKI L. REITENAUER

\begin{abstract}
This retrospective on service learning in the development of University Studies Capstones, the senior-level requirement in the University Studies general education program at Portland State University, explores how the original framers of University Studies anticipated the pitfalls of "pedagogies of whiteness" in deploying service learning as the hallmark pedagogical feature of the program; includes a case study of a Capstone course that centers on Indigenous ways of knowing, learning, and teaching through its pedagogy; and identifies the formative presence of Capstone faculty committed to anti-racist and anti-imperialist pedagogies. From a variety of institutional and disciplinary standpoints and through long association with the Capstone program, the authors move from an accounting of the historical founding of University Studies; through an up-close look at a present-day Capstone that explicitly operates from decolonizing/decolonized intentions, course content and pedagogical strategies, and student learning objectives; to a critically reflective consideration of a deeply consequential campus event related to race, racism, and "a knowledge that serves the city," as the motto of Portland State holds.
\end{abstract}

In "Service Learning as a Pedagogy of Whiteness," Mitchell, Donahue, and Young-Law introduce "strategies to interrupt whiteness in service learning and provide more educative experiences for all students" (Mitchell, Donahue, \& Young-Law, 2012, p. 623). This retrospective on service learning in the development of University Studies Capstones, the senior-level requirement in 
the University Studies general education program, explores how the original framers of University Studies anticipated the pitfalls of "pedagogies of whiteness" in deploying service learning as the hallmark pedagogical feature of the program; includes a case study of a Capstone course that centers Indigenous ways of knowing, learning, and teaching through its pedagogy; and considers the current lived experiences of Capstone faculty committed to anti-racist and anti-imperialist pedagogies. ${ }^{1}$

This reflection is particularly relevant, given Portland State University's student/faculty demographics and its advertising. Current statistics on diversity indicate that the majority of our students $(56.6 \%)$ and faculty $(73.4 \%)$ selfidentifies as "white"2 (Portland State University, n.d.; Portland State University, Office of Institutional Research and Planning, n.d.). We take pride in being "ranked highly diverse across all factors" and "ranked high in ethnic diversity," citing an Overall Diversity Score of 83 out of 100 for a ranking of \#160 nationwide, and "a student body composition that is above national average" in ethnic diversity that scores 620 out of 2,718 for a ranking of \#620 nationwide (College Factual, n.d.). Mitchell et al. caution against the possible consequences when "service learning is being implemented mostly by white faculty with mostly white students at predominantly white institutions to serve mostly poor individuals and mostly people of color" (p. 612). A mostly white teaching and learning environment, where racialized assumptions and a lack of reflective teaching and talking about race risks modeling "the missionary approach," leads both students and faculty to think that the goal of service learning is "to make 'them' more like 'us"' (p. 616). Their perfect-storm scenario for service learning as a pedagogy of whiteness was brewing in the early 199os. It is still brewing todayalthough, we contend, is attended now by greater critical reflexivity on the part of both individual instructors and the program itself, due to recent program interventions.

\section{Framing the Capstone}

The original planning for Capstone deployment clearly emphasized service learning as its foundation, declaring that the "community involvement component of this part of the program will place Portland State at the forefront of the service learning movement in American higher education" (White, 1994, p. 213). The program framers grasped the emerging national emphasis on community service and sought to align University Studies Capstones and other CBL courses with Campus Compact and the 1990 Congressional legislation incorporating service learning into the National and Community Service Act. Framers recognized that "the general education capstone is not entirely new or 
out of step with national trends. Rather, service learning has been found to have significant benefits for student learning and is now a part of the curriculum at a number of campuses" (p. 213). The program proposal climbs on the shoulders of extant giants; in addition to identifying its indebtedness to Boyer (1987), the research into best practices concentrates primarily on trends in general education assessment and reform (Association of American Colleges, 1988; Astin, 1991; Banta, 1991; Gaff, 1989, 1991, \& 1992; Kloss, 1992; Ratcliff, 1992; Twombly, 1992); on student perceptions of general education (Astin, 1992; Gaff \& Davis, 1981; Johnston et al., 1991); and on critiques of distribution models of general education (Hurtado, Astin, \& Dey, 1991; Jones, 1992; Jones \& Ratcliff, 1991).

What is not clear is whether, or how well, the linkage between service learning and white privilege received attention within the group of framers. Issues of race, racism, gender oppression, and other social and political forces were subsumed under the catchword "diversity." In fact, the framers based the recommendation to abandon a distribution model on their sense of urgency that general education at Portland State must incorporate more teaching and learning focused on diversity. "The problem of basing general education on distributions of existing courses has been illustrated by the experience of the diversity requirement," read the proposal. "The more recent controversy over incorporating a diversity requirement within the general education requirements again illustrated the weakness of attempting to build comprehensive reform on the distribution model" (White, p. 173). Identifying "diversity" as an educational experience that "ought to be integral to our students' educations" (p. 174), the framers expressed dissatisfaction with the possibility that departments might designate "diversity" courses as a strategy for increasing their share of the student credit hours (SCH) generated under the new design. "Departments have incentives to have as many of their departmental offerings as possible included on the approved list because of the assumed effects on the generation of student credit hours," wrote White (p. 173). The accompanying concern was that some diversity courses therefore might not be properly vetted or that courses containing content deemed "diverse" might find their way onto the list of approved diversity courses without integrating teaching and talking about social justice processes and exposing patterns that underlie appearances. Additionally, the delivery of diversity pedagogy through a traditional distribution model was seen as jeopardizing the centrality of teaching and talking about diversity to the revised University Studies model. "As is the case throughout the current curriculum, there are individual courses which significantly and powerfully contribute to student learning in this area," the framers observed at the time. "Yet it is not clear how this list of individual, department-based courses can consistently contribute to a coherent learning experience" (p. 197). 
Concerns that the early proliferation of diversity courses might reflect an $\mathrm{SCH}$ grab and that lack of cohesion among departments in a distribution model were consistent with Mitchell et al.s later call for reflective, holistic, and teaching/learning-centered approaches to integrating diversity into service learning. This call echoed the University Studies framers' fear that watering down diversity offerings would result in "a diminishing of the coherence and focus intended for this [diversity] requirement" (p. 173), while simultaneously hoping that this emphasis would place Portland State "among those universities and colleges that include these [diversity] issues in coursework across the curriculum" (p. 174).

It is interesting to note instances where the framers clearly anticipated Mitchell et al's advice about avoiding pedagogies of whiteness. For example, the framers understood the importance of leadership from ethnic and gender studies disciplines. Historical examples of service learning from the experience of ethnic studies faculty offer theoretical and practical approaches to teaching diversity as an integral element of community engagement (Mitchell, Donahue, \& Young-Law, 2012, especially 626, n.1; Yep \& Mitchell, 2017). Our framers sought to ensure "that persons with expertise in developing and delivering courses related to diversity, particularly those faculty who teach in the Women's Studies and Black Studies Programs, are members of the general education committee. It is this committee which will oversee and facilitate course development as well as faculty development for the general education program, and it is clearly imperative that its membership includes faculty with this expertise" (White, p. 175-176).

The fledgling years of University Studies included administrative oversight that pegged program requirements to national trends in service learning and civic engagement, and those of us involved in those early years likely remember our mutual feeling that faculty were engaged in building up-as opposed to creating-the culture of our institution around the principles of community service. Much, of course, is made of our motto, "Let Knowledge Serve the City." When we drilled down into our assumptions about what that civic contract implied, most department chairs and senior faculty reported that their individual units had always engaged in some reciprocal form of communityUniversity interaction, such as internships and cooperative education courses. Anecdotally, we understood that Portland State faculty and students had been sharing their knowledge with the City for quite some time before the boom of University Studies in the early gos transformed our motto into a mantra.

Veterans of the University Studies Program recognize the origins of Portland State's institutional emphasis on diversity as an outcome that the program helped to nurture, specifically in the Capstone experience. (See 
Capstone Program Director Seanna Kerrigan's article in this issue [Fernandez, Ludell, \& Kerrigan, 2019]). Largely as a result of University Studies Capstone assessment processes, administrative support for diversity at the University has grown consistently throughout the years. Portland State's pantheon of current vice presidents includes a Vice President for Global Diversity and Inclusion. In 1999, the University initiated a Diversity Action Council (DAC). In 2012, DAC facilitated our Diversity Action Plan, which argues that, as the largest and most diverse Oregon university, Portland State has the responsibility of modeling diversity "in all facets of its enterprise" (Portland State University Global Diversity and Inclusion, 2018), including programs, policies, and decision making. Annually, the Office of the President offers faculty Diversity Mini-grants along with the President's Diversity Awards for faculty, staff, and students who distinguish themselves by fostering equity and social justice. DAC also facilitates Portland State's Culturally Responsive Workshop and Annual Symposium. Additionally, faculty regularly receive a $C B L$ Newsletter from the Office of Academic Innovation (OAI), directing them to multiple internal resources for CBL training as well as to external CFPs for conferences and publications seeking research on service learning and community-engaged outcomes. OAI also sponsors an annual conference, Towards Pedagogies of Critical Community-based Learning, inspired by the work of Tania Mitchell and others. CBL initiatives are mirrored by institutional commitment to the scholarship of service learning, and thus we have seen the establishment in recent years of an annual Faculty Institute for Communitybased Teaching and Learning, a faculty-driven Community-Engaged Scholarship Collaborative, and the 2018 launch of a Community Engagement Research Academy. Taken together, institutional activities across units focus on extending the scholarship of service learning and engagement that University Studies jump-started decades ago. Ongoing efforts to address the quality of service learning and community engagement provide evidence that community engagement remains a solid and well-documented institutional priority, though still signaled by reliance on the proxy word, "diversity."

Maintaining focus on the ideals that drove incorporation of diversity as a pervasive feature of undergraduate (general) education at Portland State remains a matter of ongoing assessment and commitment to change when new theories and practices suggest that change is warranted. The clearest example of this assessment ethos occurred recently in the revision of the University Studies Goal previously known as "appreciation of the diversity of the human experience." Catalyzed by discussions in the University Studies Council, the Faculty Senate body that oversees University Studies, the program took on a 
comprehensive process to revise this learning goal during the 2016-17 academic year. (See the article by Lundell, Kerrigan, and Fernandez in this issue for more on that process.) The resulting name and charge of this goal more clearly invokes a critical approach: "Diversity, Equity, and Social Justice: Students will explore and analyze identity, power relationships, and social justice in historical contexts and contemporary settings from multiple perspectives" (Portland State University, University Studies, 2018). While tending toward the direction that leading scholars in service learning push, our revised language might still deserve attention. Does replacing the abstract idea of "appreciation" with the catchphrase "social justice" take us far enough? Does the still-deployed language of "diversity" (though calibrated towards a political understanding of it through the addition of "equity" and "social justice") signal that we are expressly concerned with issues of race and racism?

In The Cambridge Companion to Service Learning and Community Engagement (2017), experts review the history of service-learning pedagogy while drawing important conclusions about how to carry forward the solid foundations that have been built. Dolgon, Eatman, and Mitchell flatly advise that practitioners should "[r]estore anticolonialism and antiracism (not diversity or inclusion) as foundational principles" (2017, p. 530). Portland State's revision of its formative goal maintains the emphasis on "diversity" at the expense of alternative language that would clarify the link between service learning and teaching and talking about race. Overall, our program might consider more deeply the implication of "code talk" that allows us to signal attentiveness to race without actually naming it (Mitchell, Donahue, \& Young-Law, 2017, p. 616). A quick review of current Capstone course descriptions reveals occasional slippages into "code talk" - e.g., references to "marginalized" communities-warranting reflection; however, the abundance of descriptions that explicitly name "race," "racism," "sexism", and so on, convincingly suggests that Portland State Capstone faculty are aligned with current critically-informed practices.

The emphasis on service learning in Capstones had been consistent with institutional priorities before revision of our general education requirements gained national attention. We had enacted our mission to "let knowledge serve the city" in traditional pedagogical arrangements such as internships and cooperative education well before contemplating systemic undergraduate reform in the early 1990s. Formalization of University Studies, the Capstone Program, and CBL courses served to catalyze the kind of self-reflection that Mitchell et al. demand. Today, we see the culture of reflection embedded at all levels of the University in its pervasive emphasis on "diversity." Assessment of our programs, courses, and learning outcomes remains robust. Diversity training and 
incentives have become an integral part of annual cycles. Support and encouragement for community-engaged scholarship are visible and strong. Although we might fall short of "naming race" explicitly in cases where doing so would be warranted, institutional discourse keeps "diversity" centerstage in the way that we represent ourselves to students and communities, compelling individual faculty to confront their personal assumptions and thinking about matters including race. Ultimately, reflection on how faculty think about race, talk about race among ourselves, and discuss race with students and constituents will carry us toward a service learning pedagogy of antiracism and anticolonialism/decolonization that replaces the courage to name racism with the conviction to oppose it (Anthias \& Lloyd, 2002; Armstrong \& Ng, 2005; Bonnet, 2002; Case \& Ngo, 2017; Fox, 1992; Katz, 2003; Kishimoto, 2018; Lee \& Lutz, 2005)-as evidenced by the case study that follows.

\section{Decolonizing Service Learning: Indigenous Gardens and Food Sovereignty}

An understanding of the history of the land and the people in what is called the United States today is critical to addressing cultural/social/environmental justice, health, education, tribal sovereignty and treaty rights, issues of identity, self-determination, and providing for healthy future generations. Central to decolonization is the reassertion and revitalization of food sovereignty, which includes addressing ongoing colonized barriers for reservation and urban Native communities to access land integral to reclaiming emotional, mental, spiritual, and physical health.

The Senior Capstone course "Indigenous Gardens and Food Sovereignty" is taught from an Indigenous perspective, focusing on the resilience and resistance of Indigenous Peoples while looking at the effects of colonization and the possibilities of decolonization within Native communities via restorative practices. What does it mean to be indigenous to a place? How does the land inform who we are and guide the values of community to act on behalf of future generations? These questions serve as a foundation to the course and the rapidly emerging field of Indigenous Resurgence. Students examine impacts of colonization on Indigenous communities and their traditional foods, practices, land, health, and land/water policies. Themes of land access and management, community health, education, identity and assimilation, social/environmen$\mathrm{tal} /$ cultural justice, tribal sovereignty, and treaty rights inform the communitybased learning projects and related curricula. Revitalization of food sovereignty by reservation and urban Native American communities to reclaim health, address historical trauma, reaffirm access to land and inform land management practices as an act of self-determination is central to student understanding. 
These concepts are demonstrated through community-based learning opportunities with partners, Indigenous voices engaged through guest speakers and readings, multimedia presentations, on-site visits, and experiential hands-on activities. ${ }^{3}$ Community engagement and Indigenous land ethics guide this process. During time spent in class, outdoors in natural areas, and with community partners, students develop and participate in relationship building through community-based learning and service projects, weekly reflective writings, deep listening, dialog circles, and class/community presentations. Students critique current socio-political relations as they pertain to Indigenous Peoples and, specifically, issues regarding food sovereignty, recognizing that these themes are all related and interdependent. An understanding of Indigenous history and impacts of colonization/globalization practices is critical to developing a contemporary perspective on the social, political, and cultural issues of Indigenous Peoples regionally and globally.

In a recent example with one community partner, the Confederated Tribes of Siletz Indians Portland Area tribal office, students visited the office, participated in formal introductions, and listened to tribal elders share the history of the Siletz People and their current concerns and priorities. Students developed a deeper awareness of those concerns and how tribal and urban Native communities and organizations may plan, advocate, and take action locally, and at times, nationally and globally. With guidance and input from tribal elders and staff, Portland State students and Siletz tribal members participated in assessing the $20^{\prime} \times 30$ ' inner courtyard of the tribally owned 1970s-era business park, designing and planting an edible and medicinal learning garden of culturally significant native plants. This ongoing community partnership represents a long-term commitment, with over ten years of relationships and the ultimate implementation of culturally significant native learning gardens at Siletz's other urban offices in Salem and Eugene.

Community-based learning projects provide a context for this emerging confluence of education, culture, community, and collaboration. With a focus on re-Indigenization and reclaiming the urban landscape for food, medicine, and ceremony/healthy lifeways, this course and related fieldwork have found a timely synergy with numerous agencies and community partners working in culturally responsible restoration and education, reclamation and protection practices, and holistic land management (including informing policy). Guiding values of this work include the following:

- Remembering Our Responsibility to the 7 th Generation

- Remembering Our Responsibility to the Land

- Reciprocity and Interdependence 
- Respecting Cultural Protocols

- Cultivating Healthy Relationships "We Are All Related"

- Living, Planning, Managing and Protecting for the 7 th Generation

\section{Indigenous Perspectives and Practices: The Instructor Reflects}

What is "an Indigenous perspective?" How is it provided and by whom? How can Indigenous perspectives affect and inform general education models? Integrated into the curriculum are my understandings and experiences of traditional teachings that I received as part of what academia still refers to as an "informal" or "non-formal" education. An example of that Indigenous perspective is the recognition that Plants are our Elders, here before humans, with significant roles in shaping identity, community practices and values, and intimate relationships with the land. A practice of that perspective or knowledge is observing cultural protocols before we gather, prepare, and share tea together.

Through their reflections, class discussions, or final course evaluations, students will often share an excitement and an affirmation of Indigenous perspectives and practices resonating with their cultural identity and practices "back home." As stated earlier, Portland State has the greatest diversity of enrollment of all Oregon universities, with students from the Middle East, African nations, South and Central America, Asia, and Mexico. These students will often recognize and resonate with a shared history of colonization and its ongoing impacts on their home countries. Students have overwhelmingly evaluated these courses as "transformative," "empowering," and a highlight of their educational experience. Samples of frequent evaluation comments include: "Why can't all courses be taught this way?"; "I felt valued and learned so much from my classmates and community partner"; "Why didn't I learn about this history in high school?"; and "This information was depressing but I feel excited and hopeful about what everybody's doing ... I am not alone."

Class expectations include honoring an environment of respect. This includes maintaining respect for the ideas and experiences of everyone present and recognizing that our individual perspectives are not the only or best way to see and think about these issues. Students are asked to practice deep listening and to be receptive to others. Together, we promote an atmosphere conducive to learning and understanding. We discuss and gain a firm understanding of the "de" words like deconstruction and decolonization. However, the "re" words of remembering, reclaiming, restoration, regeneration, reaffirmation and revitalization are equally compelling and represent the dynamic energy and healing of the Indigenous Resurgence movement. 


\section{"Planting Seeds, Sharing Power, Facilitating Learning"}

In 2015, for the 2oth anniversary public celebration of the Capstone program, University Studies invited Tania Mitchell to provide a keynote address and facilitate several workshops with University Studies faculty, administrators, and students, bringing to life in multiple settings the insights and call to action she and her colleagues raised in "Service Learning as a Pedagogy of Whiteness." Inspired by Mitchell's visit, the Capstone program has continued to engage Capstone instructors in enhancing the critical stances and approaches they take in their community-based courses. Many Capstone faculty members have engaged with their colleagues around deconstructing pedagogies of whiteness through participating in University Studies-sponsored workshops and retreats, including an "Engaging Whiteness" series last academic year, and Capstone fall workshops and spring retreats focused on anti-racist, equity-based practice. Faculty working across the levels of University Studies, including several Capstone instructors, met in a year-long cohort to examine a variety of definitions in current use in the field (e.g., "service learning," "community-based learning," and "community-engaged learning," along with the application of the word "critical" to all of those pedagogies), from a number of outside institutions, in order to get clearer and more distinct about what we mean in University Studies when we use these terms.

In addition to the revisioning of the University Studies "diversity" goal to address "diversity, equity, and social justice" (DESJ), the University Studies community has also recently endeavored to identify the program's vision, mission, and teaching ethos (as discussed in other articles in this issue), the last of which includes the title of this concluding section. The processes that led to these articulations were birthed, as all processes are, out of the context operating at that moment. In 2016, we began developing the vision and mission statements and the revised DESJ goal at the height of a divisive election season which has led to a profoundly broken period in the "official" history of this nationstate. Initiated out of a collective urgency to clearly identify where, how, and for whom we stand, this collaborative effort has become only more necessary as the legacies of white supremacy and the generational trauma and violence it wreaks play themselves out in the world.

At the time of this writing, the Portland State community is grappling with the aftermath of the killing of Jason Washington-a Black Navy veteran, postal worker, father, and grandfather-by two members of our campus public safety office (which became armed after a divisive 2014 decision by the University's Board of Trustees). Pronounced and long-lived activism on the part of many members of the campus community/ies (and the greater metropolitan area in which we are situated) attended the process that resulted in the 2014 Board 
decision, and an explosion of grief has gripped the campus in the wake of an event that many, sadly, predicted would happen, given the fact of the targeting of communities of color, and particularly Black and Native peoples, for statesponsored violence.

In the aftermath of this killing, the Board of Trustees dedicated its October 4, 2018 meeting to testimony from the campus and greater communities. One of those who spoke, longtime Capstone faculty member DeEtte Waleed, offered these remarks:

Every day I walk by the sign that says "Let Knowledge Serve the City." We now have knowledge that the arming of our campus police officers caused the death of a man who was not doing anything wrong. As a matter of fact he was doing what the campus police officers should have been doing. He was breaking up a fight without using a gun .... A well-known adage in conflict resolution circles is: If your only tool is a hammer, then every problem looks like a nail. If campus police officers are trained only in how to handle guns and approach every situation that seems threatening to them with their hands on their holsters, then they don't have enough variety of tools. They need training and continuing exercises in de-escalation of conflict. They need bias awareness so they don't feel more threatened by a black man than by a white man doing the same actions .... Please let our present level of knowledge serve this campus ... [D]isarm our campus police. (D. Waleed, personal communication, October 6, 2018)

BlueHorse Skelton's Capstone course and Waleed's insights reflect the lived experience of teaching, learning, and relating within the Capstone program in University Studies at Portland State, signaling the way that many faculty, individually and collectively, recognize, accept, and work from a sense of urgency to forward antiracist, anticolonial content and practices in our courses, in our interactions with our students and with the communities in the greater metropolitan area we serve, and in our collegial relationships with each other. Indeed, from the earliest days of the University Studies and the Capstone program within it, faculty members have been drawn not only from the ranks of Portland State's most institutionally embedded faculty-namely, tenurerelated faculty teaching within departments-but directly from the communities they would come to serve through their Capstone courses (see Fernández, Lundell, and Kerrigan elsewhere in this issue). These faculty were already deeply committed to advancing socially just (and explicitly antiracist) partnership practices and to deploying liberatory pedagogies to ground students' responsible, respectful, and reciprocal interactions with those community partners. For these faculty members-some of whom are tenure-related faculty in 
"traditional" departments simultaneously engaged in community work (e.g., coauthor Dillon in Portland State's English department); some of whom are non-tenure-track faculty situated within departments such as Black Studies, Indigenous Nations Studies (e.g., coauthor BlueHorse Skelton), and Women, Gender, and Sexuality Studies (e.g., coauthor Reitenauer); and many of whom are adjunct faculty hired directly by University Studies - there has been no way to teach Capstone courses except critically. In addition to teaching a variety of Capstones across multiple partnerships, these faculty continue to contribute both formally and informally to the Program's twinned faculty support and assessment processes (through their participation in and facilitation of ongoing faculty support events, their engagement as critical colleagues in a variety of assessment processes, and their intentional cultivation of the relational nature of the Program's community of practitioners; for more on this, see Carpenter and Fitzmaurice, elsewhere in this issue). In other words, despite the hedge in the word "diversity" as articulated in the University Studies' founding document, the active recruitment of faculty who were already engaging within the community and with students in ways that went well beyond the limitations of "appreciating difference" to acting as "accomplices" (Indigenous Action Media, 2014) for social justice has grounded and catalyzed critical practice in the Program.

Our founding document didn't quite call out the promise of critical service learning in the ways that have been powerfully articulated in emerging scholarship-namely, as a forceful mechanism for engaging in the work of antiracism and anticolonialism as a vehicle for personal transformation, interpersonal relationship-building, and collective world-making. However, a truth of the lived experience of teaching and learning in Capstone and in University Studies is that many, if not most, of our faculty engage deliberately and unflinchingly to awaken ourselves and each other to our responsibilities to work to end racism in all its forms. The work, and our individual and collective works within it, continue.

W. TRACY DILLON is a professor in Portland State University's English Department, where he teaches and researches a variety of fields ranging from technical and professional writing to the literature of the Anthropocene. He offered one of the original pilot Capstones back in the day and has been teaching Capstones and CBL courses ever since.

JUDY BLUEHORSE SKeLTON, Assistant Professor, Indigenous Nations Studies Dept., Portland State University, teaches Indigenous Ecological Healing Practices, Contemporary Issues in Indian Country, Indigenous Women Leadership, and Indigenous Gardens and Food Justice. She has worked with 
federal, state, and local Native organizations and tribes throughout the Northwest for more than 25 years, conducting cultural activities and research focusing on traditional and contemporary uses of native plants for food, medicine, ceremony, and healthy lifeways. Judy is author of six collections of essays for teachers, including Native America: A Sustainable Culture (1999), and Lewis \& Clark Through Native American Eyes (2003).

VICKI L. REITENAUER serves on the faculty of the Women, Gender, and Sexuality Studies department and the University Studies program at Portland State University, specializing in developing and teaching both discipline-specific and general-education courses, including community-based learning experiences; employing critical pedagogies and reflective practice for integrative, transformative, liberatory learning; building and sustaining community partnerships; facilitating relational faculty support processes; and correlating faculty-led assessment practices.

\section{NOTES}

1. The authors of this piece include a faculty member in English involved in the earliest days of University Studies (Tracy Dillon); a faculty member in Indigenous Nations Studies teaching currently in the University Studies Capstone program (Judy BlueHorse Skelton); and a faculty member in Women, Gender, and Sexuality Studies who also serves as the faculty support coordinator in University Studies (Vicki Reitenauer).

2. Portland State diversity statistics indicate the following patterns of racial self-labeling: Students self-identify as White 56.6\%, Asian 8.4\%, Latino 12.5\%, International 7.0\%, African American $3.3 \%$, Native American 1.1\%, Multi-Ethnic 6.0\%, Native Hawaiian/Pacific Islander .06\%, and Other 4.6\% (https://www.pdx.edu/profile/snapshot-portland-state). Faculty self-identify as White $73.4 \%$, Asian 8.4\%, Black 2.4\%, Hispanic 5.9\%, Multiple Race 2.5\%, Native American 0.9\%, Pacific Islander $0.1 \%$, and Declined to indicate $6.4 \%$ (http://tableau.services.pdx.edu/Personnel/Instructional\%20and \%20Non-Instructional\%20Faculty.html).

3. Portland has the 9th largest Native American population in the U.S. and is home to many tribal and urban Native organizations, representing some of the community partners in our collaborative projects. Additional community partners include school and youth organizations, cultural community groups, governmental and community organizing groups. For more information on the community partners involved in this course or other course information, please contact Judy BlueHorse Skelton, judyblue@pdx.edu.

\section{WORKS CITED}

Anthias, F. \& Lloyd, C. (Eds.). (2002). Rethinking anti-racism: From theory to practice. London: Routledge.

Armstrong, J., \& Ng, R. (2005). A conversation between Jeannette Armstrong and Roxana Ng. In J. Lee and J. Lutz (Eds.), Situating "Race" and Racisms in Space, Time, and Theory: Critical Essays for Activists and Scholars. Montreal: McGill-Queen's University Press.

Association of American Colleges Task Group on General Education. (1988). A new vitality in general education: Planning, teaching, and supporting effective liberal learning. Washington, D.C.: Association of American Colleges. 
Astin, A. W. (1991). Assessment for excellence: The philosophy and practice of assessment and evaluation in higher education. New York: Macmillan.

- (1992). What really matters in general education: Provocative findings from a national study of student outcomes. Perspectives, (22) 1, 23-46.

Banta, T. (1991). Contemporary approaches to assessing student achievement of general education outcomes. Journal of General Education, 40, 203-23. Retrieved from http://www. jstor.org/stable/27797137.

Bonnett, A. (2002). Anti-racism. London \& New York: Routledge.

Boyer, E. L. (1987). College: The undergraduate experience in America. New York: Harper.

Case, A. \& Ngo, B. (2017). "Do we have to call it that?": The response of neoliberal multiculturalism to college. Multicultural Perspectives, 19(4), 215-22. Retrieved from https://www.tandfonline.com/doi/full/10.1080/15210960.2017.1366861.

College Factual. (n.d.). Portland State University diversity: How good is it? Retrieved from https://www.collegefactual.com/colleges/portland-state-university/student-life/diversity/.

Dolgon, C., Eatman, T. K., \& Mitchell, T. D. (2017). The devil at the crossroads: Service learning and community engagement from here on out. In C. Dolgon, T. D. Mitchell, \& T. K. Eatman (Eds.), The Cambridge Handbook of Service Learning and Community Engagement. Cambridge: Cambridge University Press.

Fernandez, 0. L Ludell, D., and Kerrigan, S. Taking high-impact practices to scale in capstone and peer mentor programs, and revising university studies' diversity learning goal. Journal of General Education, 67(3-4), 269-289.

Fox, K. (1992). Perspectives: White awareness and our responsibility to end racism. Journal of Experiential Education, 15(3), 26-30.

Gaff, J. G. (1989). General education at decade's end: The need for a second wave of reform. Change (21) 4, 10-19.

- (1991). New life for the college curriculum: Assessing achievements and furthering progress in the reform of general education. San Francisco: Jossey-Bass.

- (1992). The rhetoric and reality of general education reform: An overview." Perspective (22) 1, 47-57.

Gaff, J. G. \& Davis, M. L. (1981). Student views of general education. Liberal Education (summer), $112-23$.

Hurtado, S., Astin, A. W., \& Dey, E. L. Varieties of general education programs: An empirically based taxonomy. Journal of General Education, 40, 133-62.

Indigenous Action Media. (2014, May 4). Accomplices not allies: Abolishing the ally industrial complex. Retrieved from http://www.indigenousaction.org/accomplices-not-allies-abolishingthe-ally-industrial-complex/.

Johnston, J. S., Jr., Reardon, R. C., Kramer, G. L., Lenz, J. G., Maduros, A. S. Maduros, \& Sampson, J. P., Jr. (1991). The demand side of general education: Attending to student attitudes and understandings. Journal of General Education 40:180-200.

Jones, E. A. (1992). Is a core curriculum best for everybody? In J. L. Ratcliff (Ed.), Assessment and Curriculum Reform. San Francisco: Jossey-Bass.

Jones, E. A., \& Ratcliff, J. L. Ratcliff. (1991). Which general education curriculum is better: Core curriculum or the distributional requirement? Journal of General Education, 40, 69-101.

Katz, J. H. (2003). White awareness: for anti-racism training. Norman: University of Oklahoma Press. 
Kishimoto, K. (2018). Anti-racist pedagogy: From faculty's self-reflection to organizing within and beyond the classroom. Race Ethnicity and Education, 21(4), 540-554. DOI: 10.1080/13613324.2016.1248824.

Kloss, R. J. (1992). Can general education be assessed? One state's positive answer. The Journal of General Education 41: 177-89.

Lee, J., \& Lutz, J. (2005). Toward a critical literacy of racisms, anti-racisms, and racialization. In J. Lee \& J. Lutz (Eds.), Situating "Race" and Racisms in Space, Time, and Theory: Critical Essays for Activists and Scholars. Montreal: McGill-Queen's University Press.

Mitchell, T. D., Donahue, D. M., \& Young-Law, C. (2012). Service learning as a pedagogy of whiteness. Equity \& Excellence in Education 45(4), 612-29. D0I: 10.1080/10665684.2012.715534.

Portland State University. (n.d.). Profile: Snapshot of Portland State. Retrieved from https://www.pdx.edu/profile/snapshot-portland-state.

Portland State University, Global Diversity and Inclusion. (n.d.). Diversity action plan. Retrieved from https://www.pdx.edu/diversity/diversity-action-plan-0.

Portland State University, Office of Institutional Research and Planning. (2018). University personnel dashboards: Instructional and non-instructional faculty. Retrieved from http://tableau.services.pdx.edu/Personnel/Instructional\%20and\%20Non-Instructional\%20 Faculty.html.

Portland State University, University Studies. (2018). University Studies goals. Retrieved from https://www.pdx.edu/unst/university-studies-goals.

Ratcliff, J. L. (1992). Reconceptualizing the college curriculum. Perspectives, 22, 122-37.

Twombly, S. B. (1992). Student perspectives on general education in a research university: An exploratory Study. Journal of General Education, 41, 238-72.

White, C. R. (1994). A model for comprehensive reform in general education: Portland State University. Journal of General Education, 43(3), 168-229.

Yep, K. S., \& Mitchell, T. D. (2017). Decolonizing community engagement: Reimagining service learning through an ethnic studies lens. In C. Dolgon, T. D. Mitchell, \& T. K. Eatman (Eds.), The Cambridge Handbook of Service Learning and Community Engagement. Cambridge: Cambridge University Press. 